\title{
TINJAUAN HUKUM ISLAM TERHADAP DAMPAK PSIKOLOGIS PERKAWINAN ANAK
}

\author{
Achmad Nasrulloh \\ Universitas Islam Negeri Maulana Malik Ibrahim Malang \\ Nasrullohahmed199709@gmail.com
}

\begin{abstract}
There are many incidents when a child who is still very excited at a young age is forced to carry out a marriage due to various existing factors. For example, minimal knowledge, low economy, accidents (pregnant out of wedlock), to customs that have become family guidelines that must be applied to family members. In the findings of researchers in Simo Mulyo Baru village, Surabaya, there were 3 children who experienced this with various different factors. The results show that the psychological impact that appears on the marriage of a child varies, such as uncontrollable emotions, lack of understanding and understanding as a wife, lack of knowledge about household knowledge. From SH who has minimal knowledge and customs that forced him to get married. SH, who was still very young, also experienced this because the economy of both his parents was low and the customs that had bound his family members. Then SA had to get married because something unexpected happened, namely getting pregnant out of wedlock so that she experienced a very heavy psychological impact not being in the household such as frequent fights, uncontrollable emotions and lack of understanding of what a wife should do for her family.
\end{abstract}

Keywords: Psychological Impact, Marriage, Children

\begin{abstract}
Abstrak
Banyak kejadian disaat seorang anak yang masih sangat bersemangat dalam usia yang masih muda terpaksa harus untuk melangsungkan sebuah perkawinan yang disebabkan oleh berbagai faktor yang ada. Semisal, pengetahuan minim, ekonomi rendah, kecelakaan (hamil di luar nikah), sampai pada adat yang telah menjadi pedoman keluarga yang harus diterapkan kepada anggota keluarganya. Dalam penemuan peneliti di desa Simo mulyo baru Surabaya terdapat 3 orang anak yang mengalamo hal demikian dengan berbagai faktor yang berbeda-beda. Hasil penelitian
\end{abstract}


menunjukkan bahwa dampak psikologis yang muncul terhadap perkawinan seorang anak bermacam-macam seperti emosi tidak terkendali, kurang mengerti dan memahami sebagai seorang istri, minim pengetahuan tentang ilmu dalam berumah tangga. Dari SH yang memiliki pengetahuan minim dan adat yang membuat dia terpaksa untuk menikah. SH yang masih sangat muda juga mengalami hal demikian sebab ekonomi dari kedua orang tua yang rendah dan adat yang sudah mengikat anggota keluarganya. Kemudian SA yang harus melangsungkan perkawinan sebab hal yang terjadidi luar dugaan yakni hamil diluar nikah sehingga dia mengalami dampak psikologis yang sangat berat ketida beraa di dalam rumah tangga seperti sering mengalami pertengkeran, emosi tidak terkendali dan ketidakfahaman terhadap apa yang harus dilakukan oleh seorang istri bagi keluarganya.

Kata Kunci: Dampak Psikologis, Perkawinan, Anak

\section{Pendahuluan}

Seorang manusia tidak akan pernah lepas dengan sebuah hal yang sakral yakni sebuah pernikahan, sehingga menjadi sebuah keharusan yang hakiki bagi setiap orang. Persoalan dalam pernikahan terdiri dari hal-hal yang sangat bernilai berupa sebuah kemuliaan. Pernikahan terdapat sebuah cinta yang terdiri dari percampuran jiwa dengan jiwa sebagaimana percampuran air dengan air yang sulit untuk dipisahkan ${ }^{1}$.Meski ada pandangan bahwa menikah adalah sebuah nasib dan mencintai itu adalah takdir, karena tetap sebuah pernikahan itu tidak lepas dari sebuah cinta yang hakiki dan murni. Di sisi lain, pernikahan sebagai sebab diperbolehkannya seseorang untuk memenuhi kebutuhan biologisnya. Proses dalam kehidupan, manusia membutuhkan seorang pasangan hidup, sekaligus berharap untuk mampu membina dan membangun rumah tangga yang bahagia dan tentram di dunia maupun akhirat.

Dalam pernikahan, dipastikan berjalan melalui proses persiapan yang sangat bermacam-macam, mulai dari aspek agama, mental, sosial, ekonomi, psikologi dan lain sebagainya yang harus sudah dipersiapkan dan wajib ada agar rumah tangga yang dibina akan menjadi sebuah rumah tangga yang sakinah, mawaddah dan warahmah. Ajaran bagi sepasang suami istri untuk membangun rumah tangga yang harmonis, nyaman dan tentram telah dijelaskan didalam Q.S Ar-Rum, ayat 21 yang berbunyi:

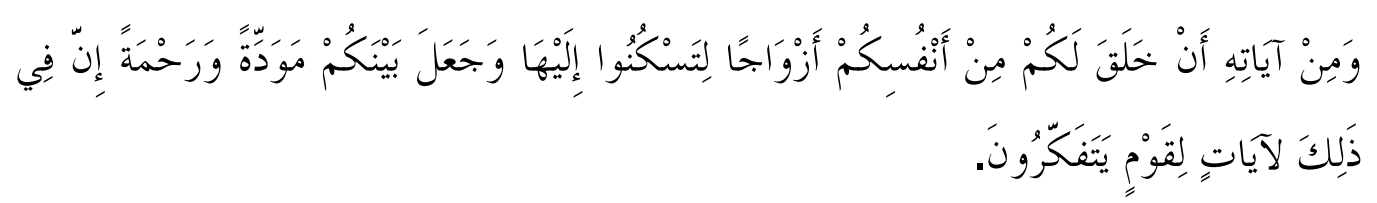

\footnotetext{
${ }^{1}$ Gus Arifin, Menikah Untuk Bahagia, 6th ed. (Jakarta: PT.Elex Media Komputindo, 2013).
} 
"Dan di antara ayat-ayat-Nya ialah Dia menciptakan untukmu istri-istri dari jenismu sendiri, supaya kamu merasa nyaman kepadanya, dan dijadikan-Nya di antaramu mawadah dan rahmah. Sesungguhnya pada yang demikian itu benar-benar terdapat tanda-tanda bagi kaum yang berpikir".

Kemudian Nabi Saw juga telah memerintahkan kepada seorang suami sebagai kepala rumah tangga yang mampu untuk mengarahkan bahtera rumah tangganya agar menjadi bahtera rumah tangga yang harmonis, tentram sesuai dengan ajaran Islam dan syari'at yang di tetapkan oleh Allah Swt, sesuai dengan hadist Nabi Saw Yang berbunyi:

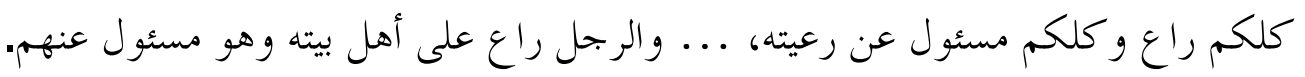

"Ketahuilah, kalian semua adalah pemimpin dan kalian semua akan dimintai pertanggungjawaban tentang apa yang dipimpinnya, Seorang suami adalah pemimpin (keluarganya) dan dia akan dimintai pertanggungjawaban tentang (perbuatan) mereka"2.

Adapun yang menjadi faktor utama dalam beberapa persiapan dalam pernikahan adalah usia perkawinan. Dalam UU No.1 Tahun 1974 Tentang Perkawinan, disebutkan bahwa usia yang paling ideal bagi seseorang untuk melangsungkan sebuah pernikahan. Bagi sepasang kekasih yang hendak melaksanakan sebuah pernikahan adalah yang sudah mencapai usia 21 tahun bagi laki-laki dan 19 tahun untuk perempuan ${ }^{3}$. Karena dalam usia tersebut adalah masa periode matang diantara keduanya dari aspek mental, psikologis, agama dan tanggung jawab.

Seiring berjalanya waktu dan masa, di beberapa tahun terakhir ini, perkawinan anak telah mengalami peningkatan terutama yang terjadi di negara yang mengalami musibah dan konflik. Menurut laporan UNICEF, menyatakan bahwa angka perkawinan anak telah mengalami penurunan sebesar 30\% sampai $50 \%$ pada tahun 2018, utamanya di wilayah Asia Selatan. Namun pada saat ini, angka tersebut mengalami kecendrungan yang konstan, bahwa sebanyak 12 juta anak perempuan menikah yang masih di bawah umur 18 tahun. Adapun Indonesia ini, sudah menempati pada urutan nomor 7 dunia dan sekaligus menjadi yang pertama di Asia Timur Pasifik ${ }^{4}$. Kasus perkawinan anak di Indonesia, yang termuat di dari Survei Sosial Ekonomi Nasional (SUSENAS) di tahun 2018, BPS mencatat angka perkawinan angka di Indonesia masih tergolong lumayan tinggi yaitu mencapai 1,2 juta kasus. ${ }^{5}$

\footnotetext{
2 Muhammad Bin Ismail Al-Bukhari, Shahih Bukhari (Dimasyq: Dar Ibn Katsir, 2002).

3 Republik Indonesia, “Undang - Undang No. 16 Tahun 2019 Tentang Perkawinan," Undang-Undang Republik Indonesia, no. 186 (2019): 8, https://jdihn.go.id/files/4/2019uu016.pdf.

4 Tutik Hamidah, "Religius Heads' Perspectives Towards the Abolition of Child Marriage: Study in

Malang East Java Indonesia,” Pertanica Journal: Sosial Sciences \& Humanities, 2019.

5 “Stop Perkawinan Anak, Kita Mulai Sekarang," Publikasi Dan Media Kementerian Pemberdayaan Perempuan Dan Perlindungan Anak, 2020, https://kemenpppa.go.id/index.php/page/read/29/2569/stop-perkawinan-anak-kita-mulaisekarang.
} 
Adapun mengenai beberapa faktor yang menjadi alasan atau dasar perkawinan anak di usia dini, diantaranya adalah perilaku seksual, kehamilan di luar nikah, sosial, budaya, tradisi adat, tingkat pendidikan yang rendah, ekonomi yang tidak mumpuni dari kedua orang tua, karakter geografis serta lemahnya suatu penegakan hukum ${ }^{6}$. Pada hakikatnya, fenomena ini juga bisa dihindari dengan adanya arahan dan pantauan dari peran orang tua. Orang tua memiliki peran penting dalam mengarahkan putra-putrinya dalam kehidupan mereka khususnya dalam sebuah pernikahan. Orang tua mendapatkan sebuah anugerah seorang anak yang memiliki hak untuk dibimbing dan dibina dan itu adalah tanggung jawab orang tua khususnya dalam mencegah terjadinya perkawinan anak di usia dini. ${ }^{7}$

Karena ada banyak pandangan yang sudah banyak terjadi, ketika seorang pasangan yang menikah dibawah umur yang telah disebutkan, rentan untuk terjadinya sebuah kdrt, pertengkaran yang menimbulkan pada perceraian, anak terlantar akibat ekonomi yang tidak stabil, tanggung jawab kurang terhadap keluarga. Kemudian ini juga terjadi, fenomena pernikahan anak dibawah umur yang masih belum siap mental dan segalanya, kemudian yang terjadi adalah sebuah perceraian, kdrt dan lain sebagaianya, umumnya di negara Indonesia ini juga sudah banyak terjadi.

Penelitian ini berjenis field research atau kajian lapangan, dengan langsung melihat dan terjun di lokasi penelitian. Penelitian ini menggunakan penelitian kualitatif, dengan mendeskripsikan berbagai sumber data primer maupun sekunder yang dihasilkan dari cara yang menggunakan metode pengumpulan data yakni wawancara, observasi dan dokumentasi. Melihat dari beberapa fenomena diatas, penulis memiliki keinginan untuk mengkaji beberapa hal yang berkaitan dengan perkawinan anak yang menjadi fenomena di desa simo mulyo baru dari aspek psikologis yang muncul di daerah tersebut.

\section{Konsep Perkawinan Dalam Hukum Islam}

Islam telah mengatur dengan sangat detail terkait sebuah perkawinan atau bisa disebut dengan pernikahan. Sebab pernikahan merupakan suatu ikatan lahir dan bathin yang sangat sakral, menggabungkan antara dua keluarga yang sejatinya tidak saling mengenal, menjadi satu kesatuan ikatan kekeluargan yang berlabel keluarga besar. Tujuan pernikahan sendiri, bukan hanya untuk memenuhi segela kepuasan biologis saja, tidak hanya untuk mencetak generasi penerus keturunan semata, namun utamanya juga dengan tujuan agar dapat membangun sebuah rumah tangga yang tentram, sejahtera nan bahagia, itu merupakan tujuan pernikahan yang utama dalam konteks Islam. Dalam Al-Qur'an telah disebutkan

\footnotetext{
${ }^{6}$ Heri Sunaryanto, “Analisis Sosial Ekonomi Faktor Penyebab Perkawinan Anak Di Bengkulu Prespektif Masyarakat Dan Pemerintah,” Jurnal Sosiologi Nusantara 5 (2019).

7 DPR \& Presiden Republik Indonesia, "Undang-Undang No 35 Tahun 2014 Tentang Perlindungan Anak," Cell 3, no. 4 (2014): 1-15,

http://dx.doi.org/10.1016/j.biochi.2015.03.025\%0Ahttp://dx.doi.org/10.1038/nature10402\%0A http://dx.doi.org/10.1038/nature21059\%0Ahttp://journal.stainkudus.ac.id/index.php/equilibriu m/article/view/1268/1127\%0Ahttp://dx.doi.org/10.1038/nrmicro2577\%0Ahttp://.
} 
dalam sebuah perintah dalam hal tersebut yang berbunyi di dalam Q.S Ar-Rum ayat: 21:

"Dan di antara tanda-tanda (kebesaran)-Nya ialah Dia menciptakan pasangan-pasangan untukmu dari jenismu sendiri, agar kamu cenderung dan merasa tenteram kepadanya, dan Dia menjadikan di antaramu rasa kasih dan sayang. Sungguh, pada yang demikian itu benar-benar terdapat tandatanda (kebesaran Allah) bagi kaum yang berpikir."

Ayat diatas menunjukkan sebuah perintah, dlaam membangun rumah tangga, juga diharuskan mempunyai tujuan untuk membangun rumah tangga yang tentram, damai dan sejahtera. Rumah tangga yang dapat diwujudkan sesuai dengan prinsip ayat diatas juga perlu didukung dengan beberapa faktor agar tujuan tersebut dapat dicapai, diantaranya yang paling utama adalah pelaku atau kedua pasangan itu sendiri yang harus mempersiapkan berbagai hal yang sangat menentukan arah rumah tangga tersebut. Islam juga telah mengajarkan bahwa sebuah pernikahan juga memandang berbagai aspek yang bertujuan agar kedua pasangan bisa saling mengisi posisi masing-masing dalam rumah tangga namun tetap dalam satu tujuan yakni membangun rumah tangga yang tentram dan damai.

Salah satu faktor tersebut adalah umur dari seorang pasangan, khususnya bagi wanita yang dipandang bakal menanggung beban yang besar dengan menjadi pemain utama dalam mengatur segaka kebutuhan didalam rumah tangga. Maka dari itu Undang-undang Republik Indonesia Nomor 1 Tahun 1974 tentang perkawinan juga memberikan syarat perkawinan dalam pasal 6 bahwa seorang wanita itu bisa melangsungkan perkawinan jika sudah mencapai umur 21 tahun, jika belum mencapai umur 21, maka harus mendapatkan izin dari orang tua terlebih dahulu ${ }^{8}$. Ini merupakan upaya dalam melangsungkan sebuah pernikahan juga perlu dipersiapkan beberapa hal terlebih dahulu, yang pasti juga berkenaan dengan umur si wanita perlu untuk digaris bawahi sehingga menunjang kesiapa mental dan secara psikologis lebih matang.

Didalam buku yang ditulis oleh Abdul Rahman Al-Ghazali yang berjudul Fikih Munakahat, disana disebutkan beberapa tujuan pernikahan dalam konteks Islam yakni disebutkan diantaranya adalah: Pertama, mampu melestarikan rantai silsilah keturunan. Ini sesuai dengan prinsip dalam al-Qur'an maupun hadist Nabi. Dalam Q.S Al-Furqon ayat 74 yang berbunyi:

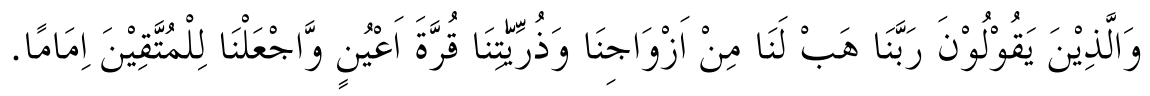

"Dan orang-orang yang berkata, "Ya Tuhan kami, anugerahkanlah kepada kami pasangan kami dan keturunan kami sebagai penyenang hati (kami), dan jadikanlah kami pemimpin bagi orang-orang yang bertakwa."

Ayat Al-Qur'an diatas mengandung sebuah makna bahwa memanjatkan permohonan doa untuk segera mendapatkan keturunan yang baik dari istrinya.

\footnotetext{
${ }^{8}$ N Pratama, "Tinjauan Hukum Islam Terhadap Dampak Pernikahan Dini Karena Orang Tua(Studi Kasus Di Dusun KenituPekon Serungkuk Kec. Belalau ...," Skripsi, 2017, 44, http://repository.radenintan.ac.id/id/eprint/2481.
} 
Maka kita sebagai umat Islam yang beriman, juga diharuskan untuk menjaga kelestarian silsilah keturunan kita denga melangsungkan sebuah pernikahan. Didalam hadist yang dikutip oleh Ibnu Qayyim, yakni hadis riwayat Ahmad dan Abu Hatim dari Anas bin Malik. Diriwayatkan bahwasanya Rasulullah memerintahkan umatnya untuk menikah dan melarang keras membujang. Nikahilah wanita yang penyayang dan subur karena sesesunguhnya Aku (Muhammad) akan bangga dengan kalian di depan para nabi pada Hari Kiamat. ${ }^{9}$ Hadist diatas juga menyebutkan bahwa Rasulullah Saw memerintah kepada ummatnya untuk menikahi seorang wanita yang subur (banyak keturunan) maka ini juga sekaligus atas dasar untuk menjaga kelestarian sebuah keturunan.

Kedua, mematuhi peraturan agama, menjaga diri dari kejahatan dan kerusakan. ${ }^{10}$ Dalam Islam juga mengajarkan kita dalam tujuan sebuah pernikahan untuk menjauhkan kita dari kejahatan dan kemaksiatan. Dengan adanya sebuah pernikahan maka kita dapat membentengi diri kita dari segala hal yang dilarang oleh Islam tersebut. Seperti yang disebutkan dalam Q.S Al-Isra' ayat: 32 yang artinya; Dan janganlah kamu mendekati zina; sesungguhnya zina itu adalah suatu perbuatan yang keji. Dan suatu jalan yang buruk ${ }^{11}$. Ayat ini menunjukkan sebuah larangan kita untuk menjauhi perkara yang bersifat zina, zina juga merupakan maksiat yang terbesar. Maka dengan sebuah adanya pernikahan, bisa menjadi faktor kita dapat menjauhi segala hal maksiat tersebut.

Ketiga, membangun sebuah prinsip untuk berani bertanggung jawab serta menerima segalah hak dan mencari segaa kebutuhan dari pernikahan yang halal saat didalam rumah tangga. Ini juga merupakan tujuan pernikahan dalam konteks Islam yang memerintahkan untuk menerima segala bentuk kewajiban dan hak dalam rumah tangga. Serta sekaligus memenuhi segalah kebutuhan dalam pernikahan disaat rumah tangga itu dengan sebuah hal yang bersifat halal. Karena itu juga menjadi faktor penting dalam keberlangsungan rumah tangga yang tentram. Dalam Q.S At-Tahrim ayat 6 yang artinya; "Wahai orang-orang yang beriman! Peliharalah dirimu dan keluargamu dari api neraka yang bahan bakarnya adalah manusia dan batu; penjaganya malaikat-malaikat yang kasar, dan keras, yang tidak durhaka kepada Allah terhadap apa yang Dia perintahkan kepada mereka dan selalu mengerjakan apa yang diperintahkan. ${ }^{12}$

Ayat diatas menunjukkan bahwa kita juga wajib menjaga dan menjauhakan keluarga kita dari siksaan api neraka. Maka itu juga sebuah kewajiban bagi kepala rumah tangga untuk menjaga diri dan keluarga dalam rumah tangganya agar selamat dari siksaan api neraka. Sebuah pernikahan juga tidak lepas dari sebuah prinsip-prinsip yang dapat menunjang keberlangsungan rumah tangga dalam pernikahan dalam konteks Islam. Berbagai prinsip tersebut mendukung dan menjadi sebuah pondasi dalam bahtera rumah tangga. Adapun prinsip-prinsip tersebut diantaranya adalah:

\footnotetext{
${ }^{9}$ Nashin Nasrullah, “Dalil Umat Harus Perbanyak Keturunan Menurut Ibnu Qayyim,” 2019, https://www.republika.co.id/berita/pzu5xa320/dalil-umat-harus-perbanyak-keturunan-menurutibnu-qayyim.

${ }^{10}$ Abdul Wahid Fadhillah, "Tinjauan Hukum Islam Terhadap Praktik Berkeluarga Menurut Pelaku Pernikahan Dini Karena Hamil Di Luar Nikah," Skripsi 53, no. 9 (2008): 287.

11 "Tafisr Web," n.d., https://tafsirweb.com/4636-surat-al-isra-ayat-32.html.

12 “At-Tahrim Ayat 6," Merdeka.com, n.d., https://www.merdeka.com/quran/at-tahrim/ayat-6.
} 
Pertama, menjalan perintah agama. Pada hakikatnya bahwa pernikahan itu untuk menjalankan perintah agama. Agama telah mengatur dengan sangat detail terkait rukun, syarat, kewajiban yang harus dipenuhi dalam pernikahan. Di samping itu juga ada beberapa hal yang sangat dianjurkan namun tidak wajib ada, seperti mahar yang layak yang dilihat dari kemampuan masing-masing personal. ${ }^{13}$ Kedua, atas dasar sebuah persetujuan dan rela. Salah satu syarat yang harus dipenuhi adalah bahwa pernikahan juga tidak ada unsur keterpaksaan dari pihak manapun yang diartikan atas dasar persetujuan keluarga dari piahk masingmasing.

Ketiga, pernikahan untuk selamanya tidak untuk sesaat. Prinsip ini merupakan yang paling utama dan sangat penting untuk dijaga dalam pikiran pasangan yang sedang dalam mekangsungkan pernikahan serta membangun rumah tangga bersama. Maka dari itu sebelum melangsungkan pernikahan, Islam telah mengajarkan untuk melihat dari calon pasangan masing-masing dari sisi aspek keluarga, karakter dan lain sebagainya. Ini sesuai yang disabdakan oleh Rasulullah Saw, dalam hadist riwayat oleh Al-Mughirah bin Syu'bah yang artinya: "Dari Al-Mughirah bin Syu'bah, bahwa ia meminang seorang wanita maka bersabda Nabi kepadanya: Apakah engkau melihat kepadanya? Berkata AlMughirah "Tidak". Bersabda Nabi: "Lihatlah kepadanya, karena dengan melihat sebelumnya itu lebih layak untuk dapat menjaga perkawinan antara keduanya ${ }^{14}$. Ini bertujuan agar ketika dalam rumah tangga, mereka bisa dengan mudah saling memahami karakter satu sama lain. Tidak menyesal ketika sudah terlanjur dalam sebuah rumah tangga. Maka perlu mendalami terlebih dahulu karakter pasangan masing-masing sebelum melangsungkan sebuah pernikahan.

Keempat, seorang Suami menjadi Pelaku utama dalam menanggung beban tanggung jawab dalam rumah tangga. Dalam hukum Islam telah dijelaskan bahwa imam dalam rumah tangga adalah seorang laki-laki. Karena itu laki-laki juga sangat diutamakan dalam menentukan arah bahtera rumah tangga tersebut. Laki-laki wajib memiliki karisma dan kendali dalam rumah tangga sehingga siapapun yang ada dialam rumah tangga tersebut dapat mudah untuk dikendalikan dan dipimpin pada jalan yang sesuai dalam syariat agama. Meskipun peran tersebut juga harus dipegang oleh istri, namun tetaplah seorang laki-laki yang menjadi pemimpin dalam rumah tangga. Sesuai dalam Q.S An-Nisa ayat 34 yang artinya;

"Laki-laki (suami) itu pelindung bagi perempuan (istri), karena Allah telah melebihkan sebagian mereka (laki-laki) atas sebagian yang lain (perempuan), dan karena mereka (laki-laki) telah memberikan nafkah dari hartanya. Maka perempuan-perempuan yang saleh adalah mereka yang taat (kepada Allah) dan menjaga diri ketika (suaminya) tidak ada, karena Allah telah menjaga (mereka). Perempuan-perempuan yang kamu khawatirkan akan nusyuz, hendaklah kamu beri nasihat kepada mereka, tinggalkanlah mereka di tempat tidur (pisah ranjang), dan (kalau perlu) pukullah mereka. Tetapi jika mereka menaatimu, maka janganlah kamu mencari-cari alasan untuk menyusahkannya. Sungguh, Allah Mahatinggi, Mahabesar. ${ }^{15}$

\footnotetext{
13 Fadhillah, "Tinjauan Hukum Islam Terhadap Praktik Berkeluarga Menurut Pelaku Pernikahan Dini Karena Hamil Di Luar Nikah." 27.

${ }^{14}$ Abdur Rahman Al-Ghazali, Fikih Munakahat (Jakarta: Kencana Pranamedia Group, 2014).

15 “An-Nisa : 34," n.d., https://www.merdeka.com/quran/an-nisa/ayat-34.
} 
Pada ayat di atas menunjukkan bahwa laki-laki merupakan seorang yang lebih kuat dan berhak memimpin seorang wanita, maka wanita lebih kepada menjadi seorang pendampin dari seorang laki-laki tersebut dalam posisi di rumah tangga bukan sebaliknya. Mahmoud Syahtout menyebutkan bahwa kelebihan seorang laki-laki atas seorang wanita itu diibaratkan dengan salah satu anggota badan, yang satu melebihi dari anggot badan yang lain. Seperti tangan kanan atas tangan kiri dan sebuah pikiran itu lebih diutamakan dari penglihatan. ${ }^{16}$

Beberapa hal diatas merupakan konsep pernikahan yang tekah diatur dalam Islam, sehingga jika sebuah pasangan yang ingin melangsungkan sebuah pernikahan dan ingin membangun rumah tangga bersama pasangannya, maka perlu untuk memenuhi beberapa hal yang telah diatus dalam Islam yang telah dijelaskan dan disebutkan diatas dari konsep, prinsip dan tujuan dalam pernikahan sesuai yang distur olehya Islam.

\section{Dampak Perkawinan Anak di Era Modern}

Dalam kehidupan yang selalu berjalan, tanpa pernah ada sebuah hal yang tidak pernah diperhitungkan dan di prioritaskan kecuali sebuah hal yang sangat sarkal dan bernilai mulia. Sumber dalam kebahagiaan yang tidak akan didapatkan melalui hal-hal yang terjadi di setiap hari, yang memiliki arti sebuah kebersamaan dan ketentraman dalam hidup yang hakiki. Kebersamaan dan ketentraman itu didapatkan dari sebuah ikatan, ikatan antara dua insan yang saling mencintai dan menyayangi satu sama lain, saling mengerti, memahami antara keduanya dari aspek karakter pribadi, prinsip, sifat dan tujuan dalam menjalani sebuah hubungan, itu adalah sebuah perkawinan.

Kemudian perkawinan dalam istilah islam lebih identik dengan istilah mistaqan ghalidhan (ikatan yang sangat kuat), ini menunjukkan bahwa Allah Swt memberikan sebuah penegasan terhadap pemahaman bahwa sebuah pernikahan adalah suatu ikatan ruhaniyyah, bathiniyyah dan dhohiriyyah yang begitu sakral antara kedua lawan jenis dalam membentuk sebuah bahtera rumah tangga ${ }^{17}$. Diantara kedua pasangan dianjurkan untuk saling mengerti dan memahami dalam menjalani sebuah rumah tangga, menjaga stabilitas keharmonisan keluarga, ketentraman dan kenyamanan dalam berumah tangga.

Kemudian pernikahan atau sebuah perkawinan dalam Islam telah diatur dalam ajaran syari'at, disana tidak tertalu eksplisit dalam menunjukkan kriteria seorang yang sudah dianggap memenuhi syarat untuk menikah, khususnya dalam hal usia seseorang. Dalam Islam, selagi rukun-rukun dan syarat dalam sebuah pernikahan sudah terpenuhi maka seseorang tersebut sudah berhak untuk melangsungkan sebuah pernikahan. Dalam prespektif fikih klasik memiliki sebuah prinsip yang tidak mengarah pada ketentuan dalam batasan usia bagi laki-laki ataupun wanita yang hendak melaksakanakan sebuah pernikahan. Maka itu juga

\footnotetext{
${ }^{16}$ Fadhillah, "Tinjauan Hukum Islam Terhadap Praktik Berkeluarga Menurut Pelaku Pernikahan Dini Karena Hamil Di Luar Nikah."

${ }^{17}$ Abdus Shamad, , Hukum Islam: Penormaan Prinsip Syari'ah Dalam Hukum Indonesia (Jakarta: Kencana, 2010).
} 
salah satu alasan yang kuat terjadinya sebuah perkawinan anak-anak yang dipandang dalam positive, ketika itu ditinjau dari sisi agama dan syariat ${ }^{18}$.

Seiring berjalanya waktu, melihat fenomena diatas dengan adanya perkembangan zaman dan prinsip dalam sebuah kehidupan, pernikahan seseorang yang belum mencapai usia yang matang, dipandangan rentan untuk terjadinya sebuah pertikaian, pertengkaran, kdrt dan lain sebagainya. Maka usia yang matang mencakup dari segala aspek yang juga harus dimiliki seseorang sebelum menjalin dan menjalani kehidupan rumah tangga seperti mental, psikologis, ekonomi, akidah dan prinsip dalam berumah tangga. Itu semua mampu dimiliki secara umum oleh seseorang, ketika orang itu sudah mencapai umur yang matang. Perkawinan anak bisa diartikan sebagai pernikahan dini, menurut pandangan The Inter African Commite (IAC) dikatakan bahwa pernikahan yang dilaksanakan pada usia dibawah 18 tahun, ketika seorang anak perempuan belum memiliki kematangan dalam aspek psikis, fisiologis, dan psikologis untuk mengemban tanggung jawab dalam rumah tangga dan siap untuk melahirkan anak ${ }^{19}$. Berdasarkan pandangan diatas, diambil sebuah garis bawah terhadap batasan usia seorang anak yang sudah mencapai pada titik kedewasaan yang mumpuni dan telah memiliki aspek kepribadian yang tangguh, psikis kokoh, mental kuat itu pada usia diatas 18 tahun.

Setiap masa dalam perkembangan seorang anak mengandung sebuah halhal yang sangat penting untuk diperhatikan. Karena memberikan pola pengasuhan dan pendidikan terhadap masa perkembangan anak sangatlah penting dan tidak lepas dari sebuah ujian dan tantangan. Dalam pandangan psikologi, sebuah masa perkembangan seseorang banyak diperhatikan sebagai dasar kepribadian seseorang yang terbentuk di masa kanak-kanak ${ }^{20}$. Maka ketika seorang anak-anak yang sedang mengalami masa-masa yang penting dalam perkembangan dan mulainya pembentukan kepribadian dari dirinya, dia akan menunjukkan berbagai perkembangan dalam berbagai aspek yang sangat menentukan dalam keberlangsungan kehidupan dalam menjalankan seluruh kegiatan dan aktifitasnya.

Adapun perkawinan seorang yang masih dalam umur yang belum mencapai usia matang memiliki beberapa hal yang perlu di tinjau ulang dan difikirkan secara matang-matang utamanya dari peran orang tua bagi mereka. Karena pengaruh dari orang tua juga sangat menentukan arah jalan kehidupan bagi seorang anak yang masih dalam perkembangan di masa kanak-kanaknya. Memang dalam UU Perkawinan dinyatakan dalam pasal 6 ayat 2 tentang syarat perkawinan, yang berbunyi: Untuk melangsungkan perkawinan seseorang yang belum mencapai umur 21 tahun, maka harus mendapat persetujuan dari kedua orang tua.

Izin disini memang harus didapatkan bagi seseorang yang masih belum cukup umur, akan tetapi semuanya itu kembali pada hak preogratif dari kedua orang tua. Karena hanya orang tua bagi mereka yang memiliki hak dan keputusan yang mutlak dalam menentukan arah kehidupan anak-anaknya. Orang tua yang memiliki peran penting, dan yang paling mengetahui kondisi psikis, mental yang

\footnotetext{
18 Yusuf Hanafi, Kontroversi Perkawinan Anak Di Bawah Umur (Bandung: Mandar Maju, 2011).

${ }^{19}$ Ariefka Listiya Elok Nuriyatur Rosyidah, “, Infografis Dampak Fisik Dan Psikologis Pernikahan Dini Bagi Remaja Perempuan,” Jurnal Kreasi Seni Dan Budaya 1, no. 103 (2017): 193.

20 Yulia Singgih Singgih D.Gunarsa, Psikologi Perkembangan Anak Dan Remaja (Jakarta: Gunung Mulia, 2008).
} 
dimiliki oleh anaknya. Maka dalam hal perkawinan, orang tua juga sangat berpengaruh terhadap hal tersebut dikarenakan bagaimana pun seorang anak pasti akan patuh terhadap apa yang di arahkan dari kedua orang tua, dikarenakan seorang anak tersebut masih dalam tahap perkembangan dalam karakter kepribadianya yang masih membutuhkan arahan dan peran kedua orang tuanya kepada mereka.

\section{Problematika dan Dampak Perkawinan Anak}

Ada beberapa hal yang didapatkan melalu hasil penelitian di lapangan bahwa ada beberapa faktor yang mempengaruhi terhadap fenomena perkawinan anak. Beberapa faktor yang disampaikan oleh Hollean adalah:

a. Problem ekonomi dalam keluarga.

b. Orang tua dari wanita meminta pertimbangan masyarakat, kepada keluarga laki-laki ketika mau mengawinkan anak wanitanya.

c. Dengan adanya perkawinan si anak wanita tersebut, maka sekaligus mengurangi beban didalam keluarga orang tua dari aspek pendidikan, ekonomi, sosial, kebutuhan hidup, mental dan lain sebagainya. ${ }^{21}$

Dari faktor yang disebutkan yang memang sering banyak terjadi adalah dalam faktor ekonomi yang kurang stabil, ketika dalam keluarga yang tidak memiliki ekonomi yang baik maka kemudian dalam pandangan orang tua akan timbul untuk menikahkan putrinya agar dapat mengurangi beban ekonomi, sosial, pendidikan dan lain sebagainya. Selain itu, memang di lingkungan masyarakat kita pada umumnya terhadap faktor penyebab terjadinya perkawinan anak, diantarany adalah:

a. Pendidikan, dalam aspek ini ketika di titik rendah baik dari pihak orang tua, anak ataupun masyarakatnya, maka memunculkan sebuah pandangan mudah untuk mengawinkan anaknya meski masih belum mencapai umur yang cukup.

b. Ekonomi, aspek ini juga termasuk memiliki pengaruh besar terhadap fenomena penyebab kasus terjadinya perkawinan anak. Ketika dalam keluarga yang berstatus ekonomi rendah, hal ini sangat rentan dan mungkin untuk terjadi karena orang tua akan beranggapan dengan mengawinkan anaknya, berarti sekaligus mengurangi beban ekonomi dalam keluarganya.

c. Keadaan anak, aspek ini mencakup dalam beberapa hal, seperti aib atau situasi dan kondisi anak perempuanya yang diketahui memiliki hubungan asmara dengan laki-laki, akhirnya agar tehindar dari aib tersebut, orang tua wanita langsung menikahkan anaknya dengan alasan agar tidak menimbulkan aib bagi keluarga di masyarakat.

d. Media sosial, semakin banyaknya informasi mengenai perilaku seks, atau hal-hal yang mengandung hal tersebut, maka seketika mempengaruhi pikiran seorang anak.

e. Adat, fenomena perkawinan di usia muda juga banyak terjadi sebab faktor ada budaya yang sudah banyak dilakukan di kalangan masyarakat sekitar, itu juga mempengaruhi pandangan orang tua terhadap hal perkawinan

${ }^{21}$ Soerjono Soekanto, Sosiologi Keluarga (Jakarta: PT. Rinneka Cipta, 2004). 
anak-anaknya.

Ada beberapa dampak psikologis yang muncul ketika seorang anak sudah menjalani sebuah rumah tangga:

a. Adanya impian yang ingin di capai akan tetapi terhalang dengan status sebuah pernikahan.

b. Problem yang terjadi di dalam keluarga.

c. Mental dan kesiapan dalam menjalani kehamilan pertama.

d. Rumah tangga berada dalam tanggung jawab seorang ibu.

Ketika seorang anak yang masih berusia dini dihadapkan dengan sebuah pernikahan, maka yang akan berdampak pada beberapa hal, dengan di tambah lingkungan keluarga yang kurang mendukung dan belum bisa mengendalikan seorang anak pada prinsip dalam berkeluarga yang baik. Beberapa hal tersebut sangat tidak bernilai ideal ketika dipaksa untuk dijalani oleh seorang anak, tapi memang itu harus diperoleh oleh seorang anak untuk menjalani sebuah keluarga di antara beberapa dampak yang terjadi.

\section{Dampak Perkawinan Anak di Desa Simo Surabaya}

Berdasarkan pengamatan peneliti dalam observasi yang telah dilakukan, di desa Simo mulyo baru Kelurahan Sukomanunggal Kota Surabaya ditemukan beberapa penemuan yang menunjukkan pada dampak psikologis sebuah perkawinan. Ada 3 responden yang sudah kami amati dan sekaligus usaha dalam mencari informasi dan keterangan kepada orang tua si 3 anak tersebut. Ada yang berinisial $\mathrm{JH}$ yang mengalami 2 faktor penyebab terjadinya perkawinan dan 4 dampak psikologisnya. Kemudian yang berinisial SH yang mengalami 3 faktor dan 3 dampak psikologisnya. Kemudian yang bernisial SA yang mengalami 2 faktor dan 2 dampak psikologis perkawinan yang dialaminya.

Berdasarkan temuan di lapangan, beberapa dampak psikologis seorang anak yang sudah melangsungkan sebuah perkawinan itu disebabkan dari minimnya sebuah pengetahuan seorang anak dan kedua orang tua, ekonomi yang tidak stabil, kecelakaan (hubungan di luar nikah), adanya sebuah adat yang sudah menjadi dasar di tengah keluarganya.

Tabel 1.1

ANAK (JH)

\begin{tabular}{|l|l|l|l|l|}
\hline No & Anak & $\begin{array}{l}\text { Pendidikan } \\
\text { Terakhir }\end{array}$ & Faktor & Dampak \\
\hline 1 & JH & SD & Adat & $\begin{array}{l}\text { Kesulitan menemukan pekerjaan } \\
\text { yang layak. }\end{array}$ \\
\hline & & & $\begin{array}{l}\text { Minim } \\
\text { Pendidikan }\end{array}$ & $\begin{array}{l}\text { Tidak Harmonis, sering salah } \\
\text { faham. }\end{array}$ \\
\hline & & & $\begin{array}{l}\text { Mental dan Pengetahuan minim } \\
\text { dalam hidup dalam rumah }\end{array}$ \\
\hline
\end{tabular}




\begin{tabular}{|l|l|l|l|l|}
\hline & & & & tangga. \\
\hline & & & & Emosional tidak terkendali. \\
\hline
\end{tabular}

Tabel 1.2

ANAK (SH)

\begin{tabular}{|l|l|l|l|l|}
\hline No & Anak & $\begin{array}{l}\text { Pendidikan } \\
\text { Terakhir }\end{array}$ & Faktor & Dampak \\
\hline 1 & SH & SD & Adat & $\begin{array}{l}\text { Sulit menemukan keserasian } \\
\text { dalam prinsip. }\end{array}$ \\
\hline & & & $\begin{array}{l}\text { Tidak ada } \\
\text { dukungan } \\
\text { keluarga }\end{array}$ & $\begin{array}{l}\text { Mental dan pengalaman minim } \\
\text { dalam berkeluarga }\end{array}$ \\
\hline
\end{tabular}

Tabel 1.3

ANAK (SA)

\begin{tabular}{|l|l|l|l|lr|}
\hline No & Anak & $\begin{array}{l}\text { Pendidikan } \\
\text { Terakhir }\end{array}$ & Faktor & Dampak & \\
\hline 1 & SA & SMP & $\begin{array}{l}\text { Kecelakaan } \\
\text { (Hamil di luar } \\
\text { nikah) }\end{array}$ & $\begin{array}{l}\text { Sering bertengkar dan } \\
\text { mengedepankan emosi masing- } \\
\text { masing }\end{array}$ \\
\hline & & & $\begin{array}{l}\text { Saling Suka } \\
\text { sama suka }\end{array}$ & $\begin{array}{l}\text { Sulit menemukan mata } \\
\text { pencaharian yang layak }\end{array}$ & \\
\hline
\end{tabular}

\section{Analisa Terhadap Dampak Psikologis Perkawinan Anak}

Berdasarkan tabel diatas, JH seorang anak dari kalangan orang tua yang memiliki ekonomi yang bisa dikatakan rendah dan sebagai pedagang sayur dan buah. Kedua orang tua yang sempat merantau untuk mencari nafkah di luar kota dan meninggalkan beberapa anak-anaknya termasuk JH dan beberapa saudarasaudara kandungnya. Si JH sendiri tetap sempat merasakan bangku sekolah di sekolah dasar ketika itu. Akan tetapi belum sampai tamat sekolah dasar si JH dibawa kedua orang tuanya untuk membantu di kediaman untuk mengurus rumah saat kedua orang tua mencari nafkah. Kemudian selang beberapa waktu yang singkat, akhirnya si JH nikah dengan seseorang laki yang hanya lulusan SMA, masih tergolong yang sama-sama masih muda. Si Laki yang berumur 20 tahun dan JH yang masih berusia 15 tahun karena juga sudah saling cinta dan suka. ${ }^{22}$

22 Wawancara dengan JH pada tanggal 16 Desember 2020. 
Kemudian pada kelanjutanya saat dalam rumah tangga, saat kedua pasangan yang masih belum memiliki rumah kediaman pribadi atau bisa dikatakan numpang di rumah orang tua. Akhirnya menimbulkan berbagai permasalahan yang terjadi, yang sudah sempat di beritahukan oleh sebagian keluarga sebelum saat pernikahan terlaksana, bahwa pernikahan yang terlalu dini akan menimbulkan permasalahan-pemasalahan. Kemudian seiring berjalanya waktu JH dan suami pergi mencari nafkah ke luar kota, seperti yang pernah di alami oleh kedua orang tua JH. Akhirnya mereka diajak oleh seorang bibi dari suami JH untuk ikut berjualan dan mencari pengalaman berdagang di luar jawa tepatnya di provinsi Irian Jaya. Disana beberapa tahun sampai memiliki 2 orang anak dan kemudian kembali lagi di kota asal yakni Surabaya, masih saja beberapa hal seperti kurang pengertian satu sama lain, saling mengedapankan ego sering tidak terkendali.

Hasil penelitian menunjukkan bahwa JH dan suami masih tergolong belum memiliki pemahaman yang mendalam tentang berkehidupan dalam rumah tangga. Karena ada disebabkan si JH yang masih tergolong muda dan dipandang terlalu terburu-buru dalam melangsungkan pernikahan yang sempat di beri nasihat oleh sebagian keluarga. Dari aspek mental, pengetahuan dalam rumah tangga, pemahaman dan pengertian sekaligus pengendalian emosi masih terbilang belum mencapai standar yang mumpuni saat bersama suami dalam menjalankan roda rumah tangga.

Kemudian dalam tabel yang kedua, terdapat kejadian yang dialami oleh SH. Dia seorang wanita yang tergolong masih sangat muda yakni sekitar umur 11 tahun dan sudah harus menikah dengan seorang laki-laki yang sudah berumur 20 tahun. Karena dalam prinsip keluarga mereka, agar menikah di usia muda diharapkan tidak terjerumus dalam pergaulan bebas dan tidak jatuh pada kemaksiatan. Kedua orang tua SH sebagai petani di desa, kemudian SH dinikah oleh suaminya dan dibawa merantau ke daerah Surabaya untuk mencari nafkah disana. Saat dalam berumah tangga, awalnya mereka masih saling berselisih pemahaman karena jauh dari kedua orang tua SH. Dalam keseharianya mereka juga sulit untuk serasi dalam setiap pemikiran dalam berumah tanggah karena dari sisi SH yang masih tergolong sangat muda yang berusia 11 tahun otomatis belum bisa menyeimbangi pemikiran dan prinsip si suami ditambah jauh dari kedua orang tua SH. Sebab tergolong yang masih sangat muda, maka SH juga kurang memahami apa yang sedang dibutuhkan oleh keluarganya, karena juga masih minim pengalaman dan pengetahuan dalam berumah tangga. Ditambah lebih parah lagi, SH dan suami sangat mengalami kesulitan dalam mencari nafkah, berbagai model dagang sudah dilakukan tapi masih saja menemui kesulitan untuk mendapatkan pekerjaan yang layak dan sesuai kemampuan yang mereka miliki. ${ }^{23}$

Hasil penelitian menunjukkan bahwa, SH dan suami yang jauh dari dukungan keluarga dalam kehidupan rumah tangganya. Di tambah SH yang masih tergolong sangat muda untuk usia pernikahan. Adat dalam keluarga yang sangat kental memberikan dampak pengaruh besar untuk SH agar dia menikah dalam kondisi yangmasih labil. Ketidakserasian, mental dan pengetahuan yang minim membuat perjalanan kehidupan rumah tangga mereka dihiasi dengan hal-hal yang

${ }^{23}$ Wawancara dengan SH pada tanggal 18 Desember 2020. 
tidak semestinya terjadi didalam keluarga. Saling mengedapankan emosi, kurang peduli terhadap kebutuhan keluarga berasal dari diri SH sebagai istri itu juga bisa dianggap sudah bakal terjadi karena melihat usia SH yang masih tergolong sangat muda yakni berusia 11 tahun.

Berdasarkan pada tabel berikutnya, yang dialami oleh SA dia dari orang tua kalangan berstatus ekonomi rendah, minim pendidikan dan kurang memiliki pengetahuan dalam rumah tangga. Ditambah dia adalah yang paling sangat membuat peneliti terkaget dan merasa kasihan. Dimana kedua pasangan ini yang didasari dari sebuah perasaan yang saling suka kemudian mereka yang sudah menjalin hubungan kekasih sangat lama. Kemudian juga kurang pantauan dan arahan dari orang tua SA, kemudian pada akhirnya terjadi suatu kecelakaan yakni hubungan di luar nikah. Pada dasarnya mereka sangat menyesali dengan hal tersebut, akan tetapi karena sudah terlanjur terjadi dalam hubungan yang sudah dirajut sangat lama akhirnya sampai terjadi seperti itu. Kemudian agar terhindar dari malu dan image yang negative, terpaksa mereka langsung dinikahkan oleh kedua orang tua dari pihak masing-masing. SA yang masih berusia 16 tahun dan suami yang masih berumur 18 tahun akhirnya menjadi pasangan suami istri secara sah setelah kejadian tersebut. Kemudian setelah itu dalam menjalani kehidupan rumah tangga, mereka saling berselisih faham, kurang mengerti pada kebutuhan keluarga. Ditambah mereka masih kesulitan dalam mencari nafkah untuk memenuhi kebutuhan hidup mereka. Kesulitan yang selalu mengiringi perjalanan kehidupan SA dan suami yang disebabkan sebuah hal yang sangat melewati batas. ${ }^{24}$

Hasil penelitian menunjukkan bahwa SA dan suami masih memiliki banyak kekurangan dan mencapai karakter yang mumpuni untuk berumah tangga. Demi menghindari malu yang sangat besar akibat kejadian yang di luar dugaan, mereka akhirnya harus terpasa menikah dalam kondisi yang belum seharusnya siap untuk menjalani kehidupan rumah tangga. Mental, pengetahuan dan prinsip yang belum sesuai dengan SA mengakibatkan berbagai pertikaian dan percekcokan tidak bisa terhindari di hubungan rumah tangga mereka. Di sisi lain kedua orang tua mereka sudah merasa selesai tugas dalam membimbing mereka berdua setelah mereka dinikahkan dengan sah atas sebab yang telah disebutkan sebelumnya. Maka ini menunjukkan betapa jelasnya bagi SA dan suami yang masih kesulitan saling mengerti dan memahami satu sama lain akibat pernikahan yang harus dilaksakan akibat kejadian yang melewati batas.

\section{Kesimpulan}

Berdasarkan hasil penelitian diatas, maka kita dapat mengambil kesimpulan bahwa dampak psikologis yang dialami oleh beberapa anak dalam sebuah perkawinan terjadi disebabkan oleh beberapa faktor. Di Desa simo mulyo baru ditemukan ada 3 anak yang mengalami dampak psikologis perkawinan yang disebabkan oleh beberapa faktor yang berbeda. Ketiga anak yang menjadi objek penelitian adalah JH, SH dan SA yang mereka semua masih berada di usia yang masih muda dibawah kisaran 16 tahun. JH yang berusia 15 tahun telah mengalami sebuah perkawinan yang disebabkan pendidikan dan pengetahuan yang minim,

${ }^{24}$ Wawancara dengan SH pada tanggal 22 Desember 2020. 
adat keluarga yang sudah menjadi pedoman keluarganya akhirnya memaksa JH untuk menikah dan mengalami berbagai dampaknya seperti emosi tak terkendali, kurang pengertian dan keharmonisan dalam rumah tangga dan sulit untuk menemukan pekerjaan.

Kemudian SH yang masih sagat muda dalam usia 11 tahun juga terdampak sebuah perkawinan yang disebabkan adat keluarg yang sangat kuat, keluarga yang memiliki pandangan agar anaknya tidak jatuh pada kemaksiatan, ditambah status ekonomi rendah dari keluarga SH dan sekaligus kurang adanya dukungan dari keluarga SH sehingga saat dalam rumah tangga $\mathrm{SH}$ dan suam sering terjadi pertikaian, mental yang belum siap untuk menjadi seorang istri, kurang perhatian kepada suami dan kurang peduli kepada keluarga sebab masih mudanya umur seorang SH. Dan bagi SA yang dipaksa melakukan sebuah perkawinan sebab adanya hal yang terjadi diuar dugaan membuat dia dan suami dalam rumah tangga setelah perkawinanya mengalami percekcokan, pertengkaran saing mengedapankan emosi dan ditambah sulitnya menemukan pekerjaa yang layak. Peneliti memberikan rekomendasi kepada seluruh orang tua dari ketiga anak tersebut agar mampu memberikan nilai edukatif dan bimbingan dalam berkeluarga sebelum mereka terjun dalam rumah tangganya masing-masing, agar tidak terjadi hal-hal yang berdampak pada sisi psikologis seorang anak. Da anak agar bisa mencapai cita-citanya terlebih dahuli, impian yang mereka ingin gapai sehingga setelah itu semua sudah tercapai baru saat orang tua untuk mengarahkn anaknya pada jenjang pernikahan untuk membangun rumah tangganya masingmasing.

\section{Daftar Pustaka}

Abdur Rahman Al-Ghazali. Fikih Munakahat. Jakarta: Kencana Pranamedia Group, 2014.

Abdus Shamad. , Hukum Islam: Penormaan Prinsip Syari'ah Dalam Hukum Indonesia. Jakarta: Kencana, 2010.

Al-Bukhari, Muhammad Bin Ismail. Shahih Bukhari. Dimasyq: Dar Ibn Katsir, 2002.

"An-Nisa : 34," n.d. https://www.merdeka.com/quran/an-nisa/ayat-34.

Merdeka.com. "At-Tahrim Ayat 6," n.d. https://www.merdeka.com/quran/attahrim/ayat-6.

DPR \& Presiden Republik Indonesia. "Undang-Undang No 35 Tahun 2014 Tentang Perlindungan Anak." Cell 3, no. 4 (2014): 1-15. http://dx.doi.org/10.1016/j.biochi.2015.03.025\%0Ahttp://dx.doi.org/10.103 8/nature10402\%0Ahttp://dx.doi.org/10.1038/nature21059\%0Ahttp://jour nal.stainkudus.ac.id/index.php/equilibrium/article/view/1268/1127\%0Ahtt p://dx.doi.org/10.1038/nrmicro2577\%0Ahttp://.

Elok Nuriyatur Rosyidah, Ariefka Listiya. “, Infografis Dampak Fisik Dan Psikologis Pernikahan Dini Bagi Remaja Perempuan.” Jurnal Kreasi Seni Dan Budaya 1, no. 103 (2017): 193.

Fadhillah, Abdul Wahid. "Tinjauan Hukum Islam Terhadap Praktik Berkeluarga Menurut Pelaku Pernikahan Dini Karena Hamil Di Luar Nikah." Skripsi 53, no. 9 (2008): 287. 
Gus Arifin. Menikah Untuk Bahagia. 6th ed. Jakarta: PT.Elex Media Komputindo, 2013.

Heri Sunaryanto. "Analisis Sosial Ekonomi Faktor Penyebab Perkawinan Anak Di Bengkulu Prespektif Masyarakat Dan Pemerintah." Jurnal Sosiologi Nusantara 5 (2019).

Nasrullah, Nashin. "Dalil Umat Harus Perbanyak Keturunan Menurut Ibnu Qayyim," 2019. https://www.republika.co.id/berita/pzu5xa320/dalil-umatharus-perbanyak-keturunan-menurut-ibnu-qayyim.

Pratama, N. "Tinjauan Hukum Islam Terhadap Dampak Pernikahan Dini Karena Orang Tua(Studi Kasus Di Dusun KenituPekon Serungkuk Kec. Belalau ...." Skripsi, 2017, 44. http://repository.radenintan.ac.id/id/eprint/2481.

Republik Indonesia. "Undang - Undang No. 16 Tahun 2019 Tentang Perkawinan.” Undang-Undang Republik Indonesia, no. 186 (2019): 8. https://jdihn.go.id/files/4/2019uu016.pdf.

Singgih D.Gunarsa, Yulia Singgih. Psikologi Perkembangan Anak Dan Remaja. Jakarta: Gunung Mulia, 2008.

Soekanto, Soerjono. Sosiologi Keluarga. Jakarta: PT. Rinneka Cipta, 2004.

Publikasi Dan Media Kementerian Pemberdayaan Perempuan Dan Perlindungan Anak. "Stop Perkawinan Anak, Kita Mulai Sekarang," 2020. https://kemenpppa.go.id/index.php/page/read/29/2569/stop-perkawinananak-kita-mulai-sekarang.

“Tafisr Web," n.d. https://tafsirweb.com/4636-surat-al-isra-ayat-32.html.

Tutik Hamidah. "Religius Heads' Perspectives Towards the Abolition of Child Marriage: Study in Malang East Java Indonesia." Pertanica Journal: Sosial Sciences \& Humanities, 2019.

Yusuf Hanafi. Kontroversi Perkawinan Anak Di Bawah Umur. Bandung: Mandar Maju, 2011.

Wawancara dengan JH pada tanggal 16 Desember 2020.

Wawancara dengan SH pada tanggal 18 Desember 2020.

Wawancara dengan SH pada tanggal 22 Desember 2020. 